\title{
Literacy mediation in marriage migration from Pakistan to the United Kingdom: appropriating bureaucratic discourses to get a visa
}

Article

Accepted Version

Capstick, T. (2016) Literacy mediation in marriage migration from Pakistan to the United Kingdom: appropriating bureaucratic discourses to get a visa. Discourse and Society, 27 (5). pp. 481-499. ISSN 0957-9265 doi: https://doi.org/10.1177/0957926516651220 Available at https://centaur.reading.ac.uk/65661/

It is advisable to refer to the publisher's version if you intend to cite from the work. See Guidance on citing.

To link to this article DOI: http://dx.doi.org/10.1177/0957926516651220

Publisher: Sage Publications

All outputs in CentAUR are protected by Intellectual Property Rights law, including copyright law. Copyright and IPR is retained by the creators or other copyright holders. Terms and conditions for use of this material are defined in the End User Agreement. 


\section{CentAUR}

Central Archive at the University of Reading

Reading's research outputs online 
Submitted to Discourse and Society

By Dr Tony Capstick

Institutional address:

Department of English Language and Applied Linguistics

University of Reading

UK

tony.capstick@gmail.com

Private address for proofs and offprints:

Flat $3 b$ Grove End House

Grove End Road

St John's Wood

NW8 9HP

UK.

Tel: 0044(0)7898136817

Title: Literacy mediation in marriage migration from Pakistan to the UK:

Challenging bureaucratic discourses to get a visa.

Size: 8,313 words (excluding abstract and references). 


\section{Abstract}

This article explores the literacy practices of a Mirpuri family and the ways family members challenge the bureaucratic discourses of migration as part of the literacy mediation they seek when applying for a visa. The central issue is to identify the institutional literacy practices in the visa application process by combining aspects of the Discourse-historical Approach (DHA) in Critical Discourse Studies (CDS) with New Literacy Studies (NLS). The article traces how visa texts are reused and recontextualized as they move between physical and social spaces in Pakistan and the UK. The aim is to identify how far the analysis of intertextual and interdiscursive relationships between discourses of migration can enhance the analysis of the literacy mediation that marginalized groups seek at a time of increasing curbs on family migration from non-European Economic Authority countries to the UK. Tracing recontextualisation in this way provides a combined framework for exploring the operations of power when analysing the extent to which bureaucratic discourses are challenged when text producers and consumers seek help filling in forms.

\section{Keywords}

Critical Discourse Analysis, New Literacy Studies, literacy mediation, Pakistan, UK, migration 


\section{Introduction}

Azad Kashmir, a disputed territory in the north of Pakistan, has a long history of migration with the UK. Mobility between the two regions increased dramatically in the twentieth century due to the colonial ties which bound the cheap labour of towns like Mirpur to the industrial heartlands of Lancashire and Yorkshire. The UK's economy became increasingly reliant on migrant labour from the 1950s onwards. Labour shortages were particularly acute in 'essential' sectors, such as agriculture, coal-mining, textiles, construction and foundry work. A deal between the Pakistan and British governments negotiated in the 1950s meant that men from the region most affected by the construction of the Mangla Dam, Mirpur, would be given the opportunity to migrate to the UK to work in those sectors of the economy where there was a shortage of labour. As a result, transnational activity between Mirpur and the UK underwent a rapid expansion as established settlers helped male family members still in Pakistan to come to the UK for work (Ballard 2003).

The initial migrants in the chain consisted mainly of single men looking for the promise of higher wages. These 'pioneer' male labour migrants later married or brought over their wives and children to the UK in a second 'family reunion' 
phase of the chain migration (Harriss and Shaw 2008). Unlike their husbands, the first-generation Pakistani female migrants to the UK rarely worked outside the home. The reasons for this low level of economic activity among first-generation female Pakistani migrants included lack of qualifications and fluency in English, as well as cultural norms which expected women to take responsibility for domestic life whilst men provided financially for the family (Dale et al. 2002). The burden of caring responsibilities, not only for children but also for elderly or disabled relatives, tended to fall on women, making employment outside the home more difficult to arrange.

Families from Mirpur who settled in the UK tended to live in close proximity to each other, forming 'ethnic colonies, within which all the most significant social, cultural and religious institutions of their homeland began to reappear' (Ballard, 2008: 41). Ballard describes how these close-knit communities enabled migrants to offer support to each other through 'networks of mutual reciprocity' (2008: 45), which were initially based on 'ideologies of kinship' (ibid.) amongst early settlers and then became rooted in actual kinship as chain migration led to growing communities of Mirpuris in UK inner cities in North West England and the Midlands. Ideologically, these communities placed importance on extended family ties in the form of 'links of mutuality which bind parents, patrilineal offspring 
and offspring's offspring into all-consuming corporate networks' (ibid.:50) and were in contrast to the assumptions of the indigenous population that migrants would quickly give up their social and cultural differences in favour of assimilation into surrounding communities (Ballard 2008). This family-reunion phase of chain migration was effectively brought to an end with the 1971 Immigration Act $^{1}$ which placed restrictions on family reunification (Demireva 2011). As a result of these immigration controls, the second phase in the chain migration transitioned to a third phase, known as marriage migration, in which spouses and dependent children became some of the few remaining groups eligible for entry to the UK.

\section{Theoretical framework}

Two overarching theoretical traditions are drawn on in this study: the social practices approach to the study of literacy, generally referred to under the label New Literacy Studies (NLS), and the Discourse-historical Approach (DHA) in Critical Discourse Studies (CDS) (see Wodak 2011; Reisigl \& Wodak 2009). New Literacy Studies concentrates on the analysis of texts and practices. In this study, these are the bureaucratic texts of immigration as I am exploring the role of

\footnotetext{
${ }^{1}$ The 1971 Immigration Act brought about the end to Commonwealth citizens' right to remain in the UK. Pakistani migrants, like migrants from elsewhere, would only be permitted to remain in the UK once they had lived and worked there for five years. However, a 'right of abode' was included in the legislation which lifted restrictions on migrants with a direct personal connection with the UK. www.legislation.gov.uk/ukpga/1972/77
} 
literacy in migration from Azad Kashmir to Lancashire. Barton and Hamilton (2000) claim that practices are neither accidental nor random but are given their structure by institutions. This includes social institutions, such as the family, education and religion. They also include those institutions which are more formally structured through rules and procedures, documentation and penalties; in this article they are the bureaucratic institutions which migrants come into contact with when migrating to the UK. This is because migrants' specific literacies have been shaped by these institutions with the result that 'some literacies are more dominant, visible and influential than others" (Barton and Hamilton 2000: 12). To understand how some literacy practices are more dominant than others, it is useful to turn to Castell's definition of power which is grounded in the relationship between institutions, values and society, just as literacy practices are patterned by institutions and the meanings and values of individuals. Castells (2014: 10) argues that:

Power is the most fundamental process in society, since society is defined around values and institutions, and what is valued and institutionalized is defined by power relationships. Power is the relational capacity that enables a social actor to influence asymmetrically the decisions of other social actor(s) in ways that favor the empowered actor's will, interests and values. (2014: 10) 
In Castells' view 'relational capacity' is the relationship between 'the subjects of power, those who are empowered and those who are subjected to such empowerment in a given context' (2009: 11). Such a view provides an understanding of how power patterns social actors' interests and values through institutional relationships between dominant and non-dominant groups, which is central to understanding how power relations pattern literacy practices. Castells argues that 'power is exercised by means of coercion (or the possibility of it) and/or by the construction of meaning on the basis of the discourses through which social actors guide their action' (2009: 10). Thus, according to Castells, these relationships play out by threats of violence or through discourses that constitute social action. It is primarily the construction of meaning on the basis of institutional discourses that this study focuses on, and not the basis of coercion. Coercion in my study can be seen in relation to the British government declining applications for visas from the spouses of British citizens.

Such questions of power are central to Critical Discourse Studies. In her seminal study exploring institutional power, Wodak looked at everyday situations, including clinical conversations between doctors and patients and school committee meetings, which depend on institutional actors conveying precise information to their clients. What Wodak found was confusion instead of 
comprehension, as obstacles to communication were established in what Castells might claim is the relational capacity, i.e. the relationship between subjects with power and those who are subject to that power. Wodak found that:

...disorders in discourse result from gaps between distinct and insufficiently coincident cognitive worlds: the gulfs that separate insiders from outsiders, members of institutions from clients of those institutions, and elites from the normal citizen uninitiated in the arcana of bureaucratic language and life. They are traceable not only to the use of unfamiliar professional or technical jargon, but also to the immanent structure of discourses themselves. (1996: 1-2)

Discourses are explored in this article in order to establish how migrants influence the relational capacity through their literacy practices which, as I established earlier, come about through the ways in which institutions shape particular literacies. I do this by looking at how migrants negotiate what Wodak describes as the 'gulfs that separate insiders from outsiders' (ibid.) as migrants use their literacy practices to favour their will over that of the empowered actors', within institutions of migration, in order to comply with the requirements of the 
application. This is because language is central to constructing the will of empowered actors in organizational settings (Wodak 2012).

\section{Literacy mediation and Cultural brokerage}

The detailed work of literacy studies shows the ways in which written texts are detachable from the social situation that originally produced them or from the place where they were first used (Blommaert 2008). These texts, Kell suggests, can move vertically as well as horizontally across contexts of asymmetrical power relations (2009). In this study I trace how texts are reused and recontextualized in this way as they move between physical and social spaces by drawing from scholarship on literacy mediation (Wagner, Messick and Spratt 1986; Malan 1996; Baynham and Prinsloo 2009). Taking this approach means exploring the help text producers and consumers seek when reading and writing as well as the discourses these texts instantiate.

This help necessarily includes knowledge of the discourses of migration as, van Dijk argues, consumers of texts require such knowledge in order to determine whether a discourse is meaningful (2008). In the family's case, this means identifying what knowledge is required to interpret the discourses of migration instantiated in the visa texts as well as identifying which individuals can be sought 
to provide this interpretation through literacy mediation. This is because, as KhosraviNik notes, 'language users and target social audiences need social and cultural knowledge in order to establish local coherence, to derive global topics and generally make sense of a piece of language thrown at them' (2015: 54). Given that not all language users possess this social and cultural knowledge, the aim of this article is to investigate the extent to which literacy mediators and cultural brokers interpret the meaning of the visa texts by drawing on both old and new 'repertories of knowledge' which, KhosraviNik claims, 'are constituted in various discourses in place both synchronically - what other discourses in the present are linked to this text/discourse - and diachronically - what other historical discourses/texts in the past are visible or tacitly relevant or called on in the way that the text communicates its messages' (ibid). I will argue that literacy mediation alone does not provide the means by which to respond to this tacit relevance but rather the concept of cultural brokerage (Robins 1996) can be employed to explore what happens when the power relations between dominant and non-dominant groups are asymmetrical and the discourses invoked by the former are unfamiliar to the latter.

I take this approach as literacy mediation has been widely used in research on literacy studies to explore the role of those people who read and write for 
somebody else (Papen 2010a) yet there is a great deal of ambiguity in how the term is employed. Baynham has suggested that a literacy mediator is 'a person who makes his or her literacy skills available to others, on a formal or informal basis, for them to accomplish specific literacy purposes' (1995: 39), while later adding that the roles of translator of spoken language and literacy mediator in multilingual encounters can overlap (Malan 1996; Baynham and Masing 2000). For Baynham and Masing, in encounters such as these, literacy mediation means not only code-switching between languages to assist those who are unfamiliar with those languages, but also switching between oral, written and visual modes. The literacy mediator therefore translates between codes and modes when reading, writing and speaking on behalf of others. Often it is the case that people with low levels of formal education have been seen to draw from the resources of a literacy mediator in order to overcome difficulties with specific texts, particularly those involving bureaucratic literacies. Fingeret (1983) demonstrates how people with low literacy tap into their existing social networks for literacy skills which they themselves do not possess but which others are able to provide. The reciprocal arrangements in these networks mean that in return for help with a literacy task, other services may be provided in return. The reciprocity shown in Mirpuri kinship networks means that traditional boundaries between home and 
school are no longer helpful as literacy mediators help family, friends and clients across domains.

For Papen, literacy mediation is 'a process that can challenge the power of dominant literacies and discourses by allowing those not commonly familiar with these practices - via a mediator - to access and deploy them for their own needs' (2010a: 79). However, it is helpful to separate how the practices of reading and writing and the practices of challenging dominant discourses are accessed and deployed by families when navigating the complexities of migration. By foregrounding the translation of dominant discourses by cultural brokers it is possible to see the ways in which discourses are challenged, as this is central to making literacies accessible to marginalized groups. Given the speed of change in UK immigration law, cultural brokers must understand multiple discourses related to migration, as well as taking into account the changing cultural contexts of British Mirpuri life in the UK and in Pakistan. Given that family members negotiate the cultural contexts of both Pakistan and the UK, it is even more important to look at how discourses circulate transnationally and how these are recontextualized in new spaces as part of transnational and intergenerational trajectories. Schools in Pakistan promote particular literacies and not others while different discourses are invoked in the dominant literacies of British bureaucracy. 
Families applying for a visa must contend with both. Hence, transnational life gives space for literacy mediators and cultural brokers to provide links between different social and cultural contexts.

The extent to which they each do this, I suggest, can be determined by the distance between the text and the discourses it invokes. Barton claims that 'the text can be central, as in the act of reading instructions from a manual; the text can be symbolic, as when swearing on the Bible; and the text can be implicit, as when talking about texts which are not present' (2007: 605). In the case of bureaucratic texts, the talk surrounding their completion moves far away from an implicit text towards talk about the discourses that texts invoke. The delineation is the distance from the text that the talk moves. To this end, a cultural broker may be able to translate discourses but not be very good at filling in forms, while a literacy mediator may be able to fill in forms but not be able to straddle the cultural contexts which grant access to multiple discourses. Examining how cultural brokers also deploy their knowledge to build links with dominant institutions for minority groups, thereby providing a bridge across contexts and discourses, reveals the contrasts with literacy mediators who do not, or do not do so as successfully as cultural brokers. 


\section{Data collection and participants}

The study presented here is part of wider research for my $\mathrm{PhD}$ looking at the dominant and vernacular literacy practices of migrants from Mirpur. During the fieldwork for the study I lived in Pakistan for over two years and travelled extensively to Mirpur for data collection (further details of the fieldwork are discussed below). On returning to the UK I spent a further four months carrying out fieldwork in Lancashire with the same families that I had been working in Mirpur. During the initial time in Pakistan I carried out a small scale research of English language testing for migrants (Capstick 2011) I asked one of the research participants, Usman, if he would like to be a key informant for my larger PhD research. Usman was 19 years old at the time and had recently married a British Mirpuri women who had returned to Lancashire after their wedding in Mirpur. Usman agreed to become a key respondent and began recording his literacy practices in a diary which he kept for two one-month periods. He would bring the diary to interviews as well as documents such as his visa application forms and I would ask him about his life and how the reading and writing that he had recorded in the diaries and on the forms fitted into it. I also interviewed many family members and friends of Usman and visited the villages of his ancestry. 
When I returned to the UK in August 2011 I continued interviewing Usman's new family in Lancashire, as Usman's wife, Nadia, lived there. I interviewed and audiorecorded Nadia three times, her sister once, her parents, Rakshanda and Shakeel, once more (having interviewed them in Mirpur during their visit there) and her brother-in-law. In the semi-structured interviews with Nadia I focused specifically on the visa application forms which she had been helping Usman complete and the visa application documentation which she was collecting. Interviews lasted from two to three hours. After Usman's second visa application was successful, he arrived in Lancashire in December 2011, and I continued to interview him about his migration and literacy practices until March 2012, which was a total of five interviews in the UK.

\section{Operationalizing the DHA for the analysis of literacy practices}

The aim of any CDA approach is to understand and explain specific social problems while focusing on the dimension of semiosis, the meaning making, from a linguistic perspective. At its core is how questions of theory relate to these specific social problems under investigation. In response to this, Wodak argues that the first question to be addressed must be the conceptual tools which are

relevant to the specific social problem and its context (2008). Further to this, 
Wodak's four-level conceptualization of context is the most significant aspect of the DHA on which I draw in this study. This is because she sees the historical, political, sociological and/or psychological dimensions of context as much a part of the analysis of a specific discursive event as the solely linguistic dimension. Embedding this conceptualisation of context within a literacy studies approach extends the analytic potential of the integrated framework when exploring the operations of power.

Based on a triangulatory approach Wodak (2004: 205), these levels were operationalised for this study by firstly establishing the broader sociopolitical and historical contexts of migration explored in the introduction to this article. Next, the specific contexts of situation of literacy mediation were explored. At this level I analyse how prospective migrants use literacy when putting together visa applications in the specific situations of, for example, dealing with an immigration solicitor. The intertextual and interdiscursive relationships between the discourses of migration are also explored in these sections, as is the immediate text of visa forms. On the second level, the intertextual and interdiscursive relationships between utterances, texts, genres and discourses are analysed in the sequential analysis of linguistic interaction. The rationale for this is that every text is related to many other texts; therefore, for any specific text, there are sets 
of other texts which are relevant to, as well as potentially incorporated in, the text. Intertextuality refers to the ways in which texts are always linked to other texts through, for example, references to a topic or to the same event. Recontextualization is where the main arguments are transferred from one text to another, and hence acquire new meanings in new contexts, while interdiscursivity hinges on the notion that discourses are linked to each other in texts (Wodak 2008).

These multiple texts which are synchronically and diachronically related to the different literacies associated with migration are investigated to establish intertextual relationships. In addition, interdiscursive analysis of migration literacies explores what Fairclough calls the "ordered set of discursive practices associated with a particular social domain or institution" (1995: 12). In this case, as different literacies are associated with different domains of life (Barton and Hamilton 2000), this level of context is combined with a literacy practices approach to explore how different visa literacies are associated with different domains of life in Pakistan and the UK. Here, NLS benefits from the DHA's attention to recontextualisation, as discourse is challenged or legitimated by the addition, deletion or rearrangement of elements of a text and the discourses that texts invoke (Wodak and Fairclough 2010). 


\section{Analysis}

\section{Rakshanda, Nadia and bureaucratic health literacies}

Rakshanda is in her mid-sixties and has lived in Lancashire with her husband, Shakeel, since the mid-1960s, when she joined him a few years after his migration to England. Nadia is their eldest daughter.

In interviews Rakshanda explained that she was unable to read and write in English. She suggested that this was because she was 'uneducated' due to her not having stayed in school long enough. Rakshanda told me that there was no need for literacy in English in her life as she has many family members who could read and write for her though she did explain that when dealing with the health issues of her daughter, Nishat, who is physically and mentally disabled, she was reliant on her daughter Nadia. When I asked Nadia about these duties, it became clear that in addition to the physical care that she gave her sister she also saw the long hours of information-seeking as part of that care. 
Nadia, as a literacy mediator for her mother, worked with Rakshanda to explain the English information that she found on the Internet. She developed healthrelated literacy practices which became central to the family's ability to cope with ever-changing regimes of funding for care, as well as providing a source of advice on how to cope with the day-to-day challenges of caring for a disabled member of the family. Thus literacy mediators like Nadia not only need to understand the bureaucratic system of healthcare but also need to be able to negotiate with what Wodak calls the 'power registers' (1996: 40) of the institution. Wodak describes these as the linguistic behaviour, or symbolic capital in Bourdieu's terms, of the powerful elite which is invested in knowledge expressed in specific institutional genres. Thus, Nadia must negotiate the power registers of the institutional setting which, I claim, she is able to do through developing her health literacy practices.

\section{Nadia's personal journey}

At the time of the research, Nadia had two children from her first marriage, a boy of ten and a girl of fourteen, and a son Ali with her second husband, Usman. Nadia is thirty years old and at the age of seventeen had an arranged marriage with her first cousin, Zeeshan. However, the marriage broke down quickly, and so Nadia and Zeeshan divorced after only a few years. Nadia always focused on 
how good her aunt and uncle had been to her before and after the divorce, which she illustrated by explaining that they had 'gifted' to her the family home she had shared with their son. This is where Nadia and her children lived after the divorce, and it is now also the home of Usman and the two children he and Nadia have had together.

\section{Becoming a cultural broker by extending literacy mediation to challenge bureaucratic discourses}

The texts that I draw on the following sections are taken from transcripts of interviews which were carried out in English and audio recorded. The specific interviews used in the following sections were carried out with Usman in Mirpur in August and September 2011 and with Nadia in Lancashire in November of the same year once I had returned to the UK.

When Usman, in Mirpur, received the letter from UKBA informing him that his (first) visa application was unsuccessful he was given two reasons. The first reason was that the Entry Clearance Officer (ECO) felt that Nadia was not earning enough money to be able to support Usman if he was unable to find work. The 
second was that insufficient documentary evidence had been provided to demonstrate that Nadia and her first husband Zeeshan were divorced.

In the first interview about the visa application, Nadia had begun by telling me that she did not know how to find information about her first marriage as no one understood that they had never registered the marriage.

1 Tony: Why wasn't the first visa application successful?

2 Nadia: Firstly it was because of my first marriage, um, basically when I got married to my ex-3 husband we had an Islamic marriage, we didn't have a registered marriage here. At the age 4 of 17 I didn't even know that existed. I did whatever my mum and dad told me and we had a 5 nikah [engagement] that's it. Er, what we needed to do was go to the registry office here and 6 register our marriage. Two or three years into the marriage I was getting older and I was 7 reading up and I realised I wasn't married and I said to my ex-husband I said I think we 8 should get registered here um it was falling apart at that stage anyway, he wasn't encouraged to do it neither was I. I think if we were more compatible if we knew that, you 10 know, our marriage was successful we would have gone ahead and done it but the marriage 11 wasn't going anywhere anyway but because of that because I didn't do it properly then basically that came as an obstruction for this marriage 'cause They believe now that because I'm British born, my ex-husband was British, they don't believe that we didn't get 14 registered here, that's one of the reasons they say they refused it on that basis. 
(Extract 1)

In this extract Nadia orients to both the bureaucratic discourses of 'registered marriage' and the non-dominant discourse of an 'Islamic marriage' (line 3). In order to position herself within these competing discourses, Nadia begins by explaining that she did not know that registered marriages 'existed' suggesting that her parents did not know either. However, a shift in talk occurs in the following line as she uses the conditional 'what we needed to do' to orient to the bureaucratic discourse of registering marriages at the register office. A further shift occurs in the narrative when she moves forward 'two or three years' and, linking the discovery to her literacy practices, explains 'I was reading up and realised I wasn't married' (lines 6-7) again by orienting to the dominant discourse of a UK marriage and not the Islamic marriage that she first mentioned in line 2. This stance on marriage is recontextualised in line 11 when Nadia explains 'because I didn't do it properly', accepting responsibility for the 'obstruction' to her new marriage and again foregrounding her orientation to a bureaucratic discourse of registering marriage. While acknowledging her role in this obstruction, Nadia ends her turn by introducing the topic of her and Zeeshan's national identity as an aspect of the decision which was made against Usman. The presupposition here is that due to their status as British citizens, the UK 
authorities would be suspicious of a British marriage which had not been registered. Nadia returns to this issue a few moments later in the interview.

1 Tony: You'd already got married to Usman, it was his visa application that they said you need 2 to provide the divorce paper

3 Nadia: Because we basically because they thought I was committing, is it bigamy, and that's 4 not true. I was being very very honest by telling them that I'd got an Islamic marriage by 5 telling them I'd got two kids I was being very honest putting my life on the table because you 6 know I knew for a fact that the Board of Registers know that Muslim girls who get arranged 7 marriage don't just get children without marriage so if I've got children who I've sent birth 8 certificates into the visa application to show I've got two children here obviously I've got I 9 have to tell them I was married at such point. But they don't believe the nikah was a marriage here, they only believe that if you go to registration office that's a marriage, that's 11 a UK marriage, and I provided enough evidence with that.

(Extract 2)

Here, Nadia recontextualises 'they don't believe that we didn't get registered here' from extract 1 by using the term 'bigamy' to signal her understanding of the high stakes involved in not registering a marriage. However, she follows this with the presupposition that the Board of Registers 'would know that Muslim girls who get arranged marriage don't just get children' thus assuming that the bureaucrats at the Board would make a link between Muslim women only having children within 
marriage. This is also an example of interdiscursivity as Nadia in the present is able to draw on discourses about marriage that she was not able to draw on when she was 17 years old. The interview continued:

1. Tony: What happens for marriage in Mirpur to be legal here?

2. Nadia: It's legal because I went to the solicitor to check all of this and the nikah is the main 3. marriage in Pakistan, that's their registration, and that is valid here.

(Extract 3)

Nadia's understanding of the bureaucratic literacy practices of marriage in Pakistan and the UK by this point is such that she is able to mediate on behalf of Usman.

Nadia then explained that after contacting her local MP she was told that she would need to provide a no trace letter to confirm that she had never been legally married in the UK. Once she understood the requirements of the no trace letter she went online to retrieve birth certificates for herself, her ex-husband and her father which she had been told she would need to provide. This, Nadia explained, she was able to do online because 'when you spend as long on the internet as I do searching for the allowances I was telling you about you know about Nishat's 
mobility allowance then you get used to how to find these things'. I interpreted this illustration of the intertextual links between bureaucratic health literacies and bureaucratic migration literacies as meaning that Nadia was able to extend her literacy practices from the searches she carried out for her health literacies and put them to use for the visa literacies. However, as Nadia extended her literacy practices to tackle the bureaucratic literacies of the UKBA, she had also to engage with the dominant discourses of these institutions, and in doing so her role shifted to that of an emerging cultural broker, straddling both dominant and non-dominant cultural contexts.

What this demonstrates is that even though the visa application procedure no longer involves a face-to-face interview in Pakistan the process of applying is not transparent enough from the forms alone. Nadia's difficulty in putting together the UK end of the application demonstrates the level of personal contact which is required in the process. The extract above which began with Nadia describing the search for the no-trace letter continued '...nobody's helping me. So basically by going in there the lady in the registry office did some research and gave me the contact details of the Home Office to request a no-trace letter.' 
This demonstrates an important aspect of literacy mediation here: To begin with, Nadia had to talk to several institutions in person to find out what to do before then going onto the Internet and using her digital literacy skills to find evidence to support a no-trace letter. Nadia gained access to institutional discourses about marriage by both speaking to information gatekeepers in their offices, where she asked pertinent questions, and then using her literacies to access information on the Internet. Wodak suggests that individuals entering an institution from outside "do not act on their own initiative, but react by answering questions, listening and providing information sought. In the institution, persons who determine the interaction occupy an institutional role ... and their language is consequently supported or legitimized by the existing institutional power" (1996: 66). Fortunately, Nadia's health literacies had provided her with some experience of dealing with institutional discourse which she was able to transfer to other institutional settings and uses to access institutional discourses related to migration.

As Nadia came across the different government websites related to her visa searches, Nadia explained that she was 'trying to understand what they were getting at', but over time she became more familiar with 'what they were on about'. The example she gave was the wording in the instructions for applying for 
a no-trace letter which included a section about the birth certificates she needed to provide. Nadia told me that she could not understand this section to begin with but by searching on the Internet she was able to work out that she needed birth certificates for herself, her ex-husband and her father. I concluded that what Nadia meant was that she became increasingly able to unpack dominant discourses, 'trying to understand what they were getting at', and make accessible the language that was at first confusing, not because of a lack of proficiency in English (she is bilingual) but because of a combination of the registers and discourses invoked which made it difficult to understand, in her words, 'what they were on about'.

The larger context of Nadia's life was central to what she understood was happening throughout this process and how she learned to deal with bureaucratic institutions. For the first application, Nadia told me (see extract 2) that because she had no written record of a divorce from Zeeshan she had believed that this would not be a problem, as she had provided the birth certificates of her two children which would be proof enough of her Islamic marriage. What Nadia misunderstood was that regardless of whether the ECO dealing with Usman's application forms understood non-dominant contexts in this way or not, the ECO's knowledge is not deployed in this way but rather decisions are based solely on 
the documentation provided. Looking back, Nadia explained how, at the time of the marriage, there was insufficient knowledge of the legal literacy practices associated with registering marriages in the UK as well as a lack of understanding of cultural practices related to marriage in the UK, which meant that Nadia was legally unmarried throughout her union with Zeeshan. Nadia oriented to the dominant discourse of legal marriage practices when she explained, 'I was reading up and I realised I wasn't married', meaning I wasn't married in the legal sense, three years after her nikah had taken place. The development of Nadia's individual literacy practices provided her with access routes to knowledge about UK bureaucratic and legal procedures to the extent that, in her words, she realised she was not married. In the dominant cultural context of the UK, this would result in a precarious legal position as many entitlements are afforded through legal marriage, particularly for women who, like Nadia, have given up work to raise a family. However, in the non-dominant context of Mirpuri reciprocity, Zeeshan's parent's gift to Nadia of the home she had been living in allowed Nadia to remarry and continue to live there with her new husband when he arrived.

Reciprocity can also be seen in the realignment of hierarchical relationships within Nadia's immediate family. Initially she is seen to act in accordance with the 
wishes of her parents and husband, a situation which changes as she takes up opportunities for literacy development. Nadia told me that she believed that she had more say in the choice of a second husband because she had 'taken over looking after my sister and making sure we knew what was what'. She described a shift in the family power relations which had partly come about through the responsibility she now had for looking after her sister, which for her was linked to managing the written records of the family's health and finances. Her position in the family had therefore been strengthened by her family's reliance on Nadia's literacy practices. In a discussion about Nadia's first meeting with Usman in Mirpur, Nadia explained that the two of them had met for 30 minutes while family members waited outside the room to see if the couple would agree to the marriage. Nadia had told me how it was not important that Usman spoke English but that it was more important that they got along together well:

1 Tony: So you weren't looking for someone who spoke English?

2 Nadia: No. I just wanted someone who who's got good morals and who could speak to my 3 parents who speak Pahari so it's important to them as well as important to me to speak to 4 his parents which we do by Skype and his brothers. My parents knew how important this was 5 after the being depressed after my first marriage but now my confidence had grown helping 6 
my family so much with Nishat I think it was really important in having that say in my next 7

marriage

(Extract 4)

Access to literacy, I claim here, means access to social power, which relates to gender roles within the family. Nadia's status as literacy mediator and cultural broker is part of the shift in gender roles which allowed Nadia to choose her second husband herself. Nadia's position was strengthened by her filling the gap in the family's knowledge about British legal documentation concerning marriage when she took on the task of brokering a no-trace letter. The gap in information here illustrates the power structure in the visa-application process which provided Nadia with an opportunity to increase her own social power. However, Nadia did not build ongoing links with these institutions in the way that Robins (1996) describes but rather developed the literacy practices with which to engage temporarily with the dominant institutions on an ad hoc basis.

\section{Cultural brokerage: challenging bureaucratic discourses about} immigration, employment and welfare

On the recommendation of her brother-in-law, Nadia contacted an immigration solicitor, Fatima, once the forms for the second application, as well as the failed 
first application, had been brought to England by relatives travelling from Mirpur. Nadia was, in her words, "leaving nothing to chance", as by this point Usman and Nadia's son Ali was already several months old and she had originally hoped that Usman would be with her in the UK in time for the birth.

After a face-to-face meeting and two telephone conversations, Fatima told Nadia exactly what the family needed to do in order to make a successful visa application. The issue identified by Fatima that I focus on here is the details of how much Nadia needed to be earning, and what documents were required to demonstrate this, in order to show that she could support Usman and her children if Usman was unable to find work on his arrival. Fatima told Nadia the amount of money she needed to earn each week and advised her on the kind of work she needed to do. Nadia then explained the situation to her brother-in-law who gave her the job that he was going to give to Usman. This job had in fact prompted a further objection from the ECO in the first application, as the job had been specially created for Usman, and it was now being specially created for Nadia. Again, the family had misunderstood the terms on which work could be provided in this way. 
Nadia described this job to Fatima who told Nadia the wording to use to describe the job in the relevant sections of Usman's visa application. Nadia explained that Fatima had 'got people working, she knows how much I need to be earning, she knows everything' and later, 'she told me the amounts I need to earn and where I need to put these on the forms'. All of this information had been missing from the advice that the previous UK solicitor had given Nadia for the first visa application. Fatima, as cultural broker and literacy mediator, straddled dominant and non-dominant contexts here as she used her knowledge of the reciprocal arrangements in Mirpuri families whereby jobs are created for family members along with her knowledge of UK employment law forbidding such practices for the purposes of immigration. Both the wording and the documentation are crucial here as Usman explained that the ECO had felt that the job-offer letter from her brother-in-law was a 'bogus letter'. Usman used the term that the ECO used in the decision letter they sent to Usman and added that 'they didn't even call him', suggesting that the ECO could have checked the content of the letter by speaking to the brother-in-law. This again demonstrates how non-dominant groups can misunderstand that the entire process for checking documentation does not extend beyond what documents are included and what wording is written on those documents. What is not allowed is additional oral information (see Appendix 1 for an excerpt from Usman's visa application). 
During this period, Nadia was only required to meet the immigration solicitor face to face when she gave her the first visa application forms and documentation, including the reasons for its failure from the UKBA, and again when the completed second visa application was ready for collection. In the first meeting, Fatima acted as a literacy mediator, asking Nadia questions and noting down her answers, in English, on a copy of the original failed visa application forms. After this second meeting Nadia and Fatima spoke by telephone in English several times, Fatima's role as mediator continuing as Nadia began to send her documents for the new application. Once Nadia had started to send in the documents that made up the new application, Fatima's role moved from offering practical advice about what documents, such as wage slips, to provide, to offering advice about the wording that must be used on the forms in order to support the required documents. Nadia, in Lancashire, kept Usman, in Mirpur, updated about these developments when they talked every few days on Skype.

When I asked Nadia what kind of things Fatima was checking for, she told me that it was making sure that what Nadia had written about her job and the house fitted with what Fatima knew about a 'good' application. Nadia gave me two examples. The first example she gave was that Fatima knew what words to use 
to describe the job and how it showed that she was earning enough money. In these moments it would seem that Fatima invoked her knowledge of dominant discourses related to employment and immigration, thereby translating different dominant discourses as well as drawing from her knowledge of the register for bureaucratic forms when rewriting the words that Nadia used in the specific genre of a visa immigration form.

The second example was when the solicitor told her they must avoid the marriage sounding like, in Fatima's words, 'a sham'. This relates to the dominant discourse in the UK about marriages which are arranged as a way of bringing further members into the country from, predominantly, South Asia. Nadia told Fatima on the phone that she lived with Usman in Mirpur for one month which Fatima recontextualised and wrote on the form in the voice of Usman "we have been cohabiting together and as a result my wife is pregnant. We are committed to remain as a married couple forever" (see Appendix 1). Fatima, Nadia told me, felt that this would prove to the UKBA that Nadia and Usman's marriage was not a sham. This is evidence that Fatima translates the bureaucratic discourse about a 'sham' marriage and provides her clients with access to the register, e.g. "co-habiting", related to this discourse. This can be juxtaposed with how Nadia defines her marriage when we were discussing her and Usman's first meeting: 
1 Tony: and how would it have changed things if he'd not had English?

2 Nadia: yeah, um, I don't think it would have bothered me as much, on our first wedding night 3 that's when we got to know each other that's when we were married and we knew that it 4 was legal and we can be with each other. We did speak English then and I forgot for a $\quad 5$ moment that he was Pakistani. I totally forgot that he is Pakistani and um I think that was 6 good.

(Extract 6)

Thus, Nadia's formulation of the marriage, to me, is that she felt legally married to Usman on her wedding night. Though this may have not been the same wording that she gave to Fatima over the phone, the process of recontextualisation was such that Fatima wrote down the words that Nadia told her and rephrased them. It would appear that Fatima is both broker and mediator here. These stages can be considered examples of recontextualisation as the forms change hands and are rewritten in a new immediate context of words and phrases by a new literacy mediator. In this substitution the wording is changed to fit the new context. In the first context, Nadia responded orally to the solicitor's questions on the phone and Fatima recast these words when she wrote them down herself on the visa application form, the second context. The immigration solicitor acted as cultural broker as Nadia's oral descriptions in English were 
transformed by a process of register-switching (Baynham and Masing 2000; Baynham 1995). This switching involved Fatima following the conventions of official forms but also invoking the dominant discourses about employment in the first example and sham marriages in the second. Fairclough (1992) refers to this as (re)formulation, as the immigration solicitor presents an interpretation of the family's earnings where Nadia is recast as a working mother with a home of her own, unlike in the first visa application which portrayed Nadia as an unemployed mother without property. This illustrates the notion at the core of CDA that that discourse constitutes social identities as well as relationships between people while also being socially constitutive in that it reproduces the status quo as well as transforming it (KhosraviNik, 2015). Chain migration is sustained in the case of the texts related to earnings while Nadia's role in the family is transformed as she becomes a wage earner.

The recontextualisation of the spoken text from the telephone conversation to the text written on the visa form demonstrates how recontextualisation is embedded within literacy mediation. However, this recontextualization involves changing the wording based on Fatima's understanding of the discourses related to employment and sham marriages, as well as immigration, knowledge which she deploys when changing the wording on the forms. It is this building up of 
knowledge of different discourses and relating them simultaneously to the wording on the form which is a feature of cultural brokerage and not literacy mediation, as literacy mediation relies more on the writing on forms while cultural brokerage relies on knowledge of the dominant and non-dominant contexts. The

everyday language of the family that Nadia used in her own voice, 'we were living together in Mirpur', needed to be transformed when translating the oral information into the bureaucratic jargon, 'we have been co-habiting together and as a result my wife is pregnant' in Usman's voice. This recontextualisation and ability to draw interdiscursively on discourses about employment and marriage are brought together through the bridging discourse of the cultural broker.

\section{Conclusion}

The examples of literacy mediation explored in this article show how Nadia appropriated bureaucratic literacy practices when preparing her husband's second visa application which were extensions of the health literacy practices distributed across the family to deal with her sister's disabilities. Looking at these literacy practices as part of the bureaucratic encounters which the family must 
engage with shows how Nadia's practices, and therefore the distributed resources of the family, changed due to the bureaucratic requirements placed upon them. Due to the policy changes regarding how much sponsors of migrants can earn, which the solicitor used to formulate her wording on the visa forms, Nadia had to take up paid work but also gained a house in time for her new husband's arrival. She was only able to do this with the help of a cultural broker, the solicitor, who was able to transform immigration discourses at the macro level and make form-filling at the micro level more transparent.

In order to explore how cultural brokers do this I needed a heuristic model with which to explore both local and global contexts. For this reason I combined NLS with the DHA by operationalising the DHA's 'four-level context model' (Wodak $2001,2011)$ to explore recontextualisation in the literacy activity of migrants. Firstly, this meant analysing the socio-political context of migration from Pakistan to the UK. Secondly, specific contexts of situation were analysed in relation to literacy mediation as a means of establishing how migrants and their families used literacy in specific situations. These two levels of context are common to NLS and not specific to the DHA. However, the DHA can enrich literacy studies at the second two levels of context through the recursive analysis of recontextualisation and the analysis of the immediate, text internal, context. By 
combining these two approaches I was able to explore the third level of context, the intertextual and interdiscursive relationships between discourses of migration as part of the analysis of literacy mediation. During this close textual analysis I worked hard not to lose sight of the meanings that individual participants brought with them to their writing. This emic perspective, taking into account the writer's reasons for saying things in a certain way, is central to NLS but less so to the DHA, hence text-based analysis alone would not have allowed me to do this. This meant that I was able to identify literacy practices related to reading, writing and migration at a range of sites, including institutional settings and non-institutional settings. The result of this triangulation can be seen in the above discussion where I found that there is a continuum of types of literacy mediation and considerable overlap with cultural brokerage when brokers translate different discourses about employment and marriage. The family, and the different literacy mediators they turned to, holds specific beliefs about language and literacy in Pakistan and the UK. Their values and beliefs influence how they use dominant and non-dominant literacies in sustaining chain migration between the two countries.

\section{Funding acknowledgement}


This article is based on PhD research which was funded by the UK's Economic and Social Research Council. This study will be published by Palgrave Macmillan in 2016.

\section{References}

Ballard, R (2003) A case of capital-rich under-development: The paradoxical consequences of successful transnational entrepreneurship from Mirpur. In Contributions to Indian sociology (n.s.), 37, (1\&2), 49-81.

Ballard, R (2008) The political economy of migration: Pakistan, Britain and the Middle East. In V.S Kalra (Ed.), Pakistani diasporas: Culture, conflict, and change (pp. 19-42). Oxford: Oxford University Press. 
Barton, D (2007) Literacy: An introduction to the ecology of written language ( $2^{\text {nd }}$ ed.). Oxford: Blackwell.

Barton, D, \& Hamilton, M (2000) Literacy practices. In D. Barton, M. Hamilton \& R. Ivanič (Eds.). Situated literacies: reading and writing in context (pp. 7-15). London: Routledge.

Baynham, M (1995) Literacy practices. London and New York: Longman.

Baynham, M, \& Prinsloo, M (Eds.) (2009). The future of literacy studies. Basingstoke: Plagrave Macmillan.

Baynham, M \& Masing, H L (2000) Mediators and mediation in multilingual literacy events. In K. Jones \& M. Martin-Jones (Eds.), Multilingual literacies: Reading and writing different worlds (pp. 189-208). Amsterdam: John Benjamins.

Blommaert, J (2008). Grassroots literacy: Writing, identity and voice in Central Africa. London: Routledge. 
Capstick, T (2011) Language and migration: the social and economic benefits of learning English in Pakistan. In H. Coleman (Ed.), Dreams and realities:

Developing countries and the English language (pp. 207- 228). London: The British Council.

Castells, M (2009) Communication power. Oxford: Oxford University Press.

Dale, A, Shaheen, N Kalra, V \& Fieldhouse, E (2002) Routes into education for young Pakistani and Bangladeshi women in the UK. Ethnic and Racial Studies, $25(6), 942-968$.

Demireva, N (2011) New migrants in the UK: Employment patterns and occupational attainment. Journal of Ethnic and Migration Studies, 37 (4), 637655.

Fairclough, N (1992) Discourse and social change. Cambridge: Polity Press.

Fairclough, N (1995) Critical discourse analysis: The critical study of language. London and New York: Longman. 
Fingeret, A (1983) Social network: A new perspective on independence and illiterate adults. Adult Education Quarterly, 33 (3), 133-146.

Harriss, K, \& Shaw, A (2008) Kinship obligations, gender and the life course: Re-writing migration from Pakistan to Britain. In V.S Kalra (Ed.), Pakistani diasporas: Culture, conflict, and change (pp. 19-42). Oxford: Oxford University Press.

KhosraviNik, M (2015) Macro and micro legitimation in discourse on Iran's nuclear programme: The case of Iranian national newspaper Kayhan. Discourse and Society, 26 (1), 52-73.

Kell, C (2009) Literacy practices, text/s and meaning making across time and space. In M. Baynham, \& M Prinsloo (Eds.), The future of literacy studies (pp. 75-99). Basingstoke: Palgrave Macmillan.

Malan, L (1996) Literacy mediation and social identity in Newtown, Eastern Cape. In M. Prinsloo, \& M. Breier (Eds.), The social uses of literacy (pp. 105122). Amsterdam: John Benjamins. 
Papen, U (2010a) Literacy mediators, scribes or brokers? : The central role of others in accomplishing reading and writing. Langage et Societe,133 (3), 63-82.

Papen, $U$ (2010b) Writing in health care contexts: Patients, power and medical knowledge. In D. Barton, \& U. Papen (Eds.), The anthropology of writing. Understanding textually-mediated worlds. (pp. 145-169). London: Continuum.

Reisigl, M \& Wodak, R (2009) Discourse and discrimination: Rhetorics of racism and antisemitism. London: Routledge.

Robins, S (1996) Cultural brokers and bricoleurs of modern and traditional literacies: land struggles in Namaqualand's coloured reserves. In M. Prinsloo, \& M. Breier (Eds.), The social uses of literacy (pp. 123- 214). Amsterdam: John Benjamins.

van Dijk, T A (2008). Discourse and context: A socio-cognitive approach. Cambridge: Cambridge University Press. 
Wagner, D A, Messick, B M, \& Spratt, J E (1986) Studying literacy in Morocco.

In B.B. Schieffeling, \& P. Gilmore (Eds.), The acquisition of literacy.

Ethnographic perspectives (pp. 223-260). Norwood, New Jersey: Abblex.

Wodak, R (1996) Disorders of discourse. (Real language series). London: Longman.

Wodak, R (2004) The discourse historical approach. In R. Wodak \& M. Meyer (Eds.), Methods of critical discourse analysis ( $2^{\text {nd }}$ ed.) (pp. 63-94). London: Sage.

Wodak, R (2008) Introduction: Discourse studies-important concepts and terms. In R. Wodak, \& M. Krzyżanowski (Eds.), Qualitative discourse analysis in the social sciences (pp. 1-29). Basingstoke: Plagrave Macmillan.

Wodak, R (2011) The discourse of politics in action: Politics as usual. Basingstoke: Palgrave Macmillan.

Wodak, R (2012) Language, power and identity. Language Teaching, 45(2), 215-233. 
Wodak, R , \& Fairclough, N (2010). Recontextualizing European higher education policies: The cases of Austria and Romania. Critical Discourse Studies, 7(1), 19-40.

\section{Author biography}

Tony currently teaches on the MA TESOL programme at Lancaster University, UK. He completed his PhD in Applied Linguistics in 2014 in which he combined the Discourse-Historical Approach in Critical Discourse Studies with the

ethnographic perspective of New Literacy Studies to explore the multilingual literacy practices of migrants in Pakistan and the UK. He is currently writing up his PhD study as a monograph to be published by Palgrave Macmillan. Prior to teaching at Lancaster, Tony taught at universities in Pakistan, Romania, Korea and Indonesia and was the English Language Adviser at the British Council in Islamabad from 2010-2011. 
Appendix 1: Usman's visa application extract. 
8.4.19 Do you intend to livo with your sponsor permanently?
Put a crosis in in the roleran: $00 x$

8.4.12 Havo you lived with your sponsor in a relationship

liko a marriago or civil partinership at any time fincluding

Put a crass fxil tho roto partinership ceremony)?

Ves No

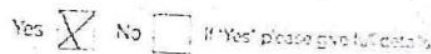

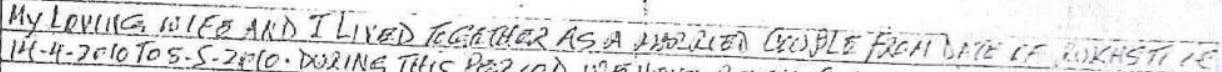

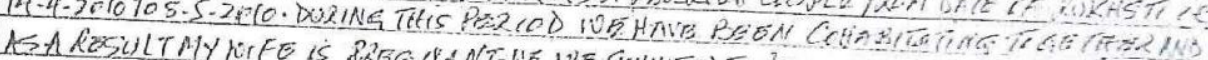

8.4.13 Havo you or your sponsor ever been

a long-iorm mamiago like relation ever been married or in

Put a cross $(x)$ in tho roterent bor

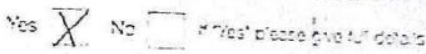

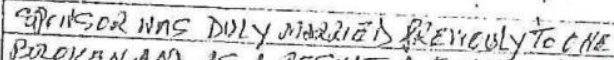
BROKBNANA AS A RSSULT A FINAL ISLAM

TALAQ'EBTAIIED EII $20-3-2007-$ ISLARK

8.4.14 Doos your sponsor have any children?

Pul a cross (x) in the ritran! tox

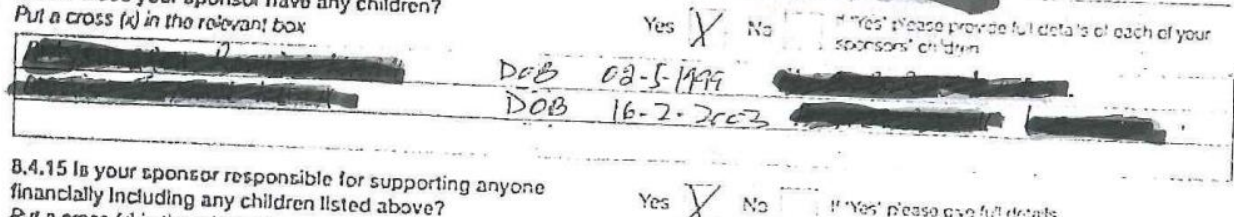

financlasty Including

Put a cross $(x)$ in tho rolevent box

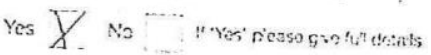

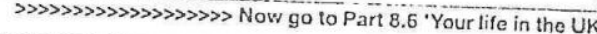

8.5 Otherdependants

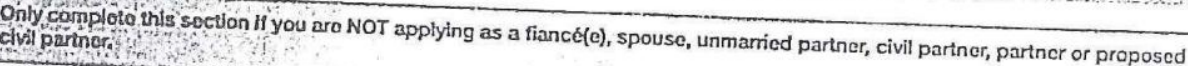

8.5.7 How oxactly aro you and your sponsor related?

8.5.2 Who do you livo with at the moment and what is your rolathonshlp fo them?

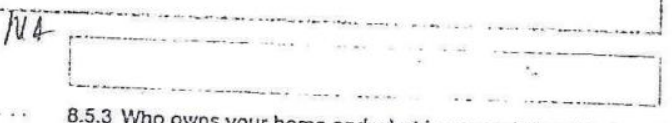

8.5 .3 Who owns your home and what is your relationship to
them? Nit:

-.......

molations bo fo financlally and what is your rolationshlp to thom?

8.5.5 What other family members do you have and where do Hest they livo?

8.5.6 How ofton do you soo thoso family members?

8.5.7 is your sponsor responsible for anyone clse's financial / th if

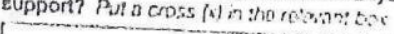

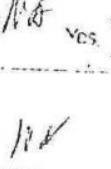

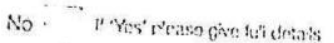
. 